\title{
A NEW FUNCTION OF PRISON INDUSTRY AND PRIVATE PRISONS IN DEVELOPED COUNTRIES, AND THE POSSIBILITY OF THEIR IMPLEMENTATION IN THE REPUBLIC OF SERBIA
}

\author{
UDC 343.8
}

\author{
Emil Turković* \\ University of Niš, Faculty of Law, Niš, Republic of Serbia
}

\begin{abstract}
In the 1990s, various countries had a different approach to the problems related to prisoners' labor. In the United States, the concept of prison labor could survive only in such developed states as New York, Pennsylvania and Massachusetts which could cope with the burden of keeping unproductive prisons. Under the impact of the penal reform and upon the adoption of new penal legislation in these states, the old American tradition of labor prisons gave way to a new standard which implied that convicted offenders had to learn different crafts while in prison but they were excluded from the public labor market when at large. The new industrial program, which was thus engendered, has significantly contributed to spreading the reformist functions of prison labor. Organized prison labor had always been strongly supported by penal reformers in the north of the United States but, in the mid-1980s, as the penal reformers moved away from that part of the United States, the concept of organized prison labor no longer had a significant political and legislative impact. The influence of penal reformers and the idea of instituting convict labor (but without competition in the labor market) had a strong influence on government politicians both at the federal and state government levels. The reformers endeavored to ensure the prisoners' welfare and enable all prisoners to work and participate in the labor market as competitive workforce, both by leasing their labor and through the sale of final products on the free market.
\end{abstract}

Key words: prisoners' labor, unproductive prisons, prisoners' welfare, competitive workforce.

\section{INTRODUCTION}

In the United States, penitentiary institutions as we know them today did not exist until the 1860s. The first prisons were made in Illinois, by the US army, while prisons run by civilian officials did not originate in the United States until 1890. Local jails had been

Received March $4^{\text {th }}, 2017 /$ Accepted November $16^{\text {th }}, 2017$

Corresponding author: Emil Turković, "PhD Candidate, University of Niš, Faculty of Law, Serbia

E-mail: emilturkovic@hotmail.com 
formed forty years before the state allowed individual businessmen to manage penitentiary institutions as well as private, joint stock, for-profit institutions (Greene, 1977: 1).

At the time, the penitentiary system was most useful to private entrepreneurs who hired prisoners as workforce; prisoners' work was supervised by prison staff who were paid a fee agreed between the institutions and private companies. The new standards for the development and regulation of prison labor were finally stipulated in the recommendations of the US Industrial Commission in 1900, which was created by the Republican Chamber of the US Senate.

The support platform to fight for better conditions of prisoners' labor was taken over by the institution called the Federation of Forced or Prison Labor of USA, which increasingly occupied an important place in American penological theory and practice. It took cautious political activity at the state level to prevent this body to take influence from its predecessor, i.e. the reformers of the development of prison labor. However, the continuous growth of influence of the national Federation for Prison Labor of the USA and their unshakable resistance to criticism of imprisonment and convicts' labor, has done a lot to prepare public opinion, especially politicians for the new prison industry and new forms of private prisons, whose formation is associated with the United States (Reynolds, 1994: 21).

Republicans as well as Democrats began to understand the situation in prisons and to yield to the persistent operation of the FPI (Federal Prison Industries). In 1886, Carol D. Wright, Commissioner of Labor in Cleveland (Ohio), defended the contractors for whom the prisoners worked, but in 1896 he changed his mind and reported the existence of unfair competition because prisoners' work was far cheaper than the labor of free citizens (Zatz, 2008: 868).

The Commission founded by the Republican Chamber in the US Senate, which was responsible for the industrial development of convict labor within penitentiary institutions, strongly supported the New York system of using prison labor under state administration. In fact, twelve of the thirteen resolutions passed by this Commission highlighted the superiority of this system over all other systems of organization of convicts' labor. Also, a significant set of statistical data, collected by this Commission, revealed the higher profits acquired from contract activities within the prison. However, the Commission later took a slightly different position, arguing that "the most desirable system for the employment of prisoners is the one that envisages aspects, primarily for punishment, but also for the reform of prisoners, and that one that makes the least competition with work outside prisons, and, secondly, which increases income in the United States"(McKelvey, 1934: 200). Many reports, including the report of the Republican Commission for Industrial Development of convicts' labor in the United States, warned about a decrease in prisoners' earnings and the working conditions in prisons. At the same time, they looked forward to the comparative expansion of the convict labor industry; later on, one of these reports propagated the piece-price system, where the prisoners through their work produced finished goods and sold them at a competitive price on the free market, using the prison administration (Smith, 2005: 10).

\section{A NEW FEATURE OF THE PRISON INDUSTRY AND PRISONERS' LABOR IN THE MODERN WORLD}

The reception of new theories on the reform and industrialization of prison labor was not always positive. These national reports showed lack of responsibility for the state budgets, which were contradictory in terms of performance and profit gained by prisoners' work. Another commission from Illinois, which originally advocated for the New York prison labor 
system and industrialization plan, was alarmed by the discovery that a well-organized administrative body failed to provide jobs for more than one-third of state prisoners and for those prisoners in district prisons, as well as by the discouraging financial results of prisoners' labor. The New York prison system and convicts' labor industrialization plan was designed and developed by the federal government, with the aim to employ convicts on an industrial scale. According to the plan, convicted offenders were to be engaged in the production of goods and products, which are primarily necessary to maintain prison presence on the free market. Therefore, it was necessary to adopt an act at the federal level, which would envisage that a particular prison shall ask the enterprises to apply for a particular job or the production of goods, whereby they must conclude a contract with the prison industry, even if the price they offer is higher than that offered by other company on the free market (Busse, Brown, 2003: 58).

As mentioned, along with Massachusetts and Ohio, New York is one of the states that promote the system of organizing convict labor and industrialization of production within penitentiary institutions.

However, while states were accustomed to receiving larger budgets for the maintenance of their prison facilities, the time when a single prison or prisons and prisoners' work were financed from the state or federal budget was over. The recommendations of the Industrial Commission were widely used and cited in the following years of struggle to increase profits from prisoners' labor. A resolution of the Commission, which proposed a definitive action revived the old agitation to curb cross-border trade in goods made in prisons. Several states were obliged to prevent the adoption of similar laws that regulate the import of prison products from other countries, requiring branding or license for the importer, or a similar registration restricting the trade in goods produced by work of convicts (McKelvey, 1934: 267).

Congress banned the import of such commodities from abroad. However, state laws were attacked in the courts, and the "extreme laws" of New York and Ohio were subject to severe criticism. In the United States, New York and Ohio laws were perceived as "extreme" laws because they did not coincide with the laws of other states that regulate the matter of prisoners' labor. Among other things, these laws did not give primacy to workers and employees at large; they required that the rights of prisoners working in the penitentiary facilities be equal to those of the free employees. The problem of prison labor reached its peak at the end of the century. While the aggressive action of organized prison labor exerted a significant impact on the economic sphere, politicians (eager to attract more voters) were still in favor of the competitiveness of industrial interest in the prison industry (Busse, Brown, 2003: 49).

Given the fact that the US government made a list of prohibited goods (coming from the prison industry) which were not to be resold by the states, the United States seemed to have taken on a form of police state government because the Federal Government determined the manner and forms of sale of goods and dictated the terms on the market to a greater extent than it is allowed in the modern legal systems. The impact of this problem started to expand. Escaping from the brutality of propagating the new theory, most states were able (in one way or another) to provide employment to most of its convicts; despite a brief crisis, the old system was able to stand on its feet in the state prisons that support the correctional federal prison system.

In Pennsylvania, New York and (to a lesser extent) in Massachusetts, a new situation developed, mainly relying on strictly penological approach to prison labor that would no 
longer exploit convicts' work. It was fortunate for the prison labor reformers, who were thus encouraged to develop their ideas on prison labor which they might have been forced to abandon in the previous period as an economic necessity for self-preservation of penitentiary institutions. Regular prisons in these states had a dilemma. The system of prison labor in Pennsylvania became a farce; in New York, lax administration provided work for about onethird of convicts in prisons; prisoners in Massachusetts were idling around the outdated machinery, while supervisors tried to maintain the old system of convict labor alive. If prisons adopt reformist methods and seek to ensure a constructive coexistence of prisoners, they must also learn how to provide conditions to hold convicts quite satisfied and disciplined; and the need to maintain obedience to persons who work in prisons or to return to the brutal punishment (Reynolds, 1994: 33).

These are some of the questions and answers that labor legislation has been forced to consider since 1900s. Today, the states that overcame these issues during the transition from the disciplinary to the reformist method encountered similar problems again. The 20th century bears witness of the successful implementation of two additional alternative systems of convict labor: a camping trip, and a minimum security farm. States which excluded their prison products from the public market could not make a satisfactory industrial activity in their prisons. The effect was (and continues to be) an incentive for the development of activities of prisons of reformatory character, either through discussion, or (as it is said "on the air") professional-recreational activity, except in those prisons in which prisoners are handed over to "mess idleness" (McKelvey, 1934: 268).

However, in the last few decades we may observe considerable improvements in the industrialization of convict labor in the US penitentiary institutions. US companies that once searched for cheap labor in places such as Mexico and China returned these jobs back to the US and, in most cases, the jobs are entrusted to penitentiary institutions. Thus, convicts' labor has become much cheaper again. Paid between 93 cents and $\$ 4.73$ per day, without benefits, prisoners are a source of cheap labor for about 100 large companies across the United States. This has a huge impact on the daily lives of ordinary citizens, even though it is not so apparent at first sight (McKelvey, 1934: 200).

Any American citizen who has an insurance or investment, uses a bank account or tools of trade, drives a car or flies a plane, has a child at school, goes to the dentist's, or calls the service center may benefit from the labor of convicts in prisons because most of the renowned companies use prison labor to produce goods and provide services that will be launched on the free market, at lower prices. First of all, prison labor is much cheaper than regular employees, which enables these successful companies to retain the market value of their products or services. If you have purchased products from Starbucks, Nintendo, Victoria Secret, JC Penney, Sears, Wal-Mart, K-Mart, Eddie Bauer, Wendy, Proctor \& Gamble, Johnson \& Johnson, Fruit of the Loom, Samsung, Caterpillar, Sara Lee, Quaker Oats, Mary Kay, or Microsoft, you are part of this system. When a large number of prisoners are placed in state and federal prisons, the US taxpayers subsidize low salaries and profits, because they are paying for the inmates' accommodation, housing, and health care. When prisoners are placed in private prisons, their work is a way to earn more money; thus, through their labor (which is much cheaper than the labor of regular employees) they bear part of the costs of their life in the penitentiary institutions and contribute to the development of convict prison industry. In other words, prison labor is an effective way for companies to increase their profits and potential profits without sharing them with the employees (Wade, 2013: 1). 
Criticism against the prisoners' "idleness" is not uncommon; yet, over six hundred thousand or probably close to a million prisoners are working full time in the penitentiary institutions throughout the United States. In particular, some of the main products of convict labor, such as office furniture, are used at state universities and the state or federal government offices. Prisoners also receive hotel reservations at corporate call centers, make body armor for the US Army, make chic fashion accessories, and produce license plates (Zatz, 2008: 869).

These "prison industry" programs for producing goods or providing services are sold to other government agencies or the private sector, with the aim to achieve the highest profit. From the beginning of the New Deal era, the prison industry was strongly regulated through the well-known Ashurst-Sumners amendments, which banned the sale of products of prison industries in interstate transactions. However, government customers have always been excluded, as part of a wider New Deal compromise that allowed prison labor for "national use". Restrictions on other purchases were gradually loosened over the past thirty years. In addition, a few restrictions apply to the increasing sales of services performed by prisoners. Today, the prison industry generates $\$ 2$ billion in annual revenue (Zatz, 2008: 870).

Prison industries are now operating within a number of different organizational forms. The most frequent organizational form implies a government agency (usually within the department responsible for supervising the operation of the penitentiary system); generally known as a system of "national accounts", these agencies fully manage the prison facilities and organize the inmates' work within the institutions, the sale of products and collection of profits. An alternative system of "contracts" signed with the prison management vests the control functions with private companies that operate the program (Zatz, 2008: 884-885).

The latter of these two systems, the alternative system of private prisons, emerged in the United States at the beginning of the nineteenth century, and was widely expanded until late 1890. It largely disappeared in the early twentieth century, and now it seems to have reappeared. The most common but least visible form of prison labor are the so-called "prison chores." Prison housework is a subspecies of the system of "state of use", in which the penitentiary facility manages production and uses products of convicts' labor, given that prisoners directly contribute to the operation of the prison facility by cooking meals, doing laundry or cleaning installations and facilities (McKelvey, 1934: 195).

Prisoners can be directly used by different administrative units, as support for holiday parties and other events. While it may be difficult to determine the benefits from this work, a written account from the State of Kentucky shows the estimated amount of three million dollars that the district saved in the year 2006 as a result of convict labor (McKelvey, 1934: 110).

Prisoners who work in these different programs are usually paid by the day or by the hour. Wages for inmates' work vary in different jurisdictions, and from program to program, but in 2002 the average wages ranged from seventeen cents to five dollars and thirty-five cents an hour. Therefore, these wages commonly fall below the federal minimum wage set by the Fair Labor Standards Act (FLSA). Prisoners have noticed the discrepancy and complained by invoking the provision of this Act. This Act refers to providing work for prisoners within penitentiary institutions (Zatz, 2008: 870). 


\section{DEVElopMEnT OF PRIVATE PRISONS}

Private prisons are institutions in which individuals are physically placed by a third party that has a contract with a government agency or directly with the government. Companies that organize the operation of private prisons, generally, have signed agreements with the governments of their states, which have convicted the offenders; the states pay a daily allowance or a monthly amount for each prisoner who is imprisoned in this private institution.

In the United States, the privatization of prisons first emerged in the period immediately after the American Revolution. As America was deprived of the possibility to send criminals and undesirable groups of people to the colonies, the United States first resorted to detaining them on ships that were used as ship-prisons, but these prisons soon became overcrowded.

Partial transfer of administration of the San Quentin prison from the private to the public sector brought disagreement on ways of managing prisons and expediency of executing prison sentences, but it did not mark the end of the privatization of prisons. The next phase began with the reconstruction period (1865-1876) in the south, towards the end of the Civil War. After freeing their slaves, plantations owners and businessmen had to find a replacement for the workforce. In early 1868, the rental of prisoners allowed private companies to replace their workforce. This system remained in place until the beginning of the 20th century (Chang, Thompkins, 2002: 40).

During the last two decades, the US prison population quadrupled, with about 1.9 million people behind bars in federal, state and local prison. Corporations are looking for opportunities to profit from the prison population. This paper examines two large areas through which corporations benefit from prisoner's work: prison industries and the privatization of prisons. This part of the paper first provides the key explanation on the prisoners' work in private prisons in the United States and reports on the current state of affairs in the privatization of prisons and prison industrialization. Then, the author examines the effects they have on the organized work of prisoners, and discusses the labor union's strategy and proposals for fighting the expansion of corporate power in the correctional industry. Also, private prisons and prison industries entail different advantages and disadvantages of instituting such a system of penitentiary institution that relies on the work of prisoners (Chang, Thompkins, 2002: 45). The question arises whether such a system could come alive in our country.

Private prisons have begun to emerge only recently, but the link between the private sector and criminal-correctional institution has a long and often troubled history. In the 19th and early 20th century, it was common for prisons in the United States to rent inmates' work to private contracting parties, which then exploited convicts as slaves on plantations and in factories. This method was beneficial for the two contracting parties, but the prisoners suffered, and were exploited for work, because no officials in the penitentiary system or private contractors cared for the prisoners' welfare. This method remained popular until the 20th century reforms. Ironically, the change did not come out of concern for the welfare of prisoners, but was initiated by the labor unions which saw the cheap convicts' labor as a threat to the operation of workers' trade unions. The increased influence of trade unions pushed for adopting a legal framework that would limit the influence of convict labor in the US economy. However, there was a significant change at the end of the 20th century. In the 1980s, state and local prisons together held a total of 500,000 prisoners. In addition, the privatization was due, and private prisons or "closed for profit" penitentiary institutions become more common. This explosion in the prison population generated the 
emergence of the "prison industrial complex", joining economic and political interests of corporate profits and the power elite of the prison complex. Also, in response to the new philosophy through vocational rehabilitation and training, using the profits from prison industries to reduce closing costs of prisoners, the private sector has started again to increase (Field, 1987: 8).

During the Presidency of Ronald Reagan from 1981 to 1989 , there was a movement to influence the US government to privatize and reduce the costs in different government sectors, starting with postal services, transportation and some parts of the military.

Private prisons were part of the correctional system in the past, and some state prisons practiced contracting convicts' labor in order to meet various prisoner needs, but the current privatization of penitentiary institution exceeds all previous efforts in this direction. The current private prisons take full control of the prison administration concerning the organization of convicts' work and production within the penitentiary institutions, and certainly the revenue collection from convict's work. This only describes the size of participation of private companies, which are making a profit in the prison system of convict labor. Also, the correctional system and private companies have started business relations in many other areas. Private companies provide food, medical services job training and education for prisoners. The expansion of these two processes has caused a lot of controversy in recent years.

Private prisons and their companies reflect the fact that the privatization of prisons could solve the problem of overcrowding; moreover, private prisons are claimed to be much cheaper and more efficient than government penitentiary institutions. Such arguments are invalid, whereas the issue of legality of private prisons has not been comprehensively regulated. Here the question arises whether the transfer of power and prison administration from the state criminal-correctional system to the private sector is constitutionally based. The very essence of disapproval of prison privatization is the question of political implications. Their legal authorities and legislative power is transferred to the politically unfit persons or party. If the private sector is vested with too extensive authorities, it would call for a greater responsibility of the legislative power for transferring power to the politically unfit person or party. Still no part of the common law, based on jurisprudence, it sounded on the unconstitutionality of transferring power over the work of prisons and prisoners in the private sector (Henry, Gran, 2008: 1-9).

Article 1 of the Constitution of the United States states that the legislative powers are vested in Congress, which means that they cannot be transferred to other parts of the government or third (private) parties. The legislative process must be carried out by the elected members of Congress, who are responsible for the adoption and implementation of all laws. In this respect, the transfer of legislative power would lead to undemocratic distribution of power and law enforcement. However, this disapproval was reduced over time. Therefore, out of necessity, part of the legislative powers had to be transferred to certain bodies or agencies that have the expertise and resources to make laws which, in this specific case, regulate the operation of private prisons and prisoners.

As the transfer of these powers to private sector has to be constitutional, it is necessary to determine the legal framework and specific limitations which prevent potential abuse of authority and the law. This is a general principle behind the idea of legal regulation of issues pertaining to convicts in private prisons and prison industries. However, based on jurisprudence and precedents, common law cannot adopt a set of laws that would regulate this area. Instead of enacting legislation on this matter, the United States passed statutes on the 
regulation of private prisons. So far, four states have brought these statutes: Tennessee, Texas, New Mexico and Florida. All of these statutes have their advantages and disadvantages. For example, the Texas statute allows the employment of prisoners in private prisons, if they are well-disciplined and are not a risk to flee. Another legislative act is essential for the functioning and organization of prison labor in private penitentiary institutions. It is the Private Prisons Information Act (2011), passed by Congress in the 112th session in 2011. This Act requires private prisons and correctional facilities, holding inmates under a contract with the US Federal Government, to make all the information available to the public just like the federal prisons and correctional facilities under the direct administration of the US Government. This Act was repealed last year, but penologist and other reformers advocate for its rapid reactivation.

Advocates of private prison management and convicts' labor in the prison industry point out that prisons administered by the US Government are not doing a good job, primarily given the fact that the prison population has increased to $110 \%$ of prison capacity. It is estimated that every year the prison population increased by an additional $5.6 \%$ of convicts, and that the costs of their imprisonment exceeded ten billion dollars a year (Zatz, 2008: 871).

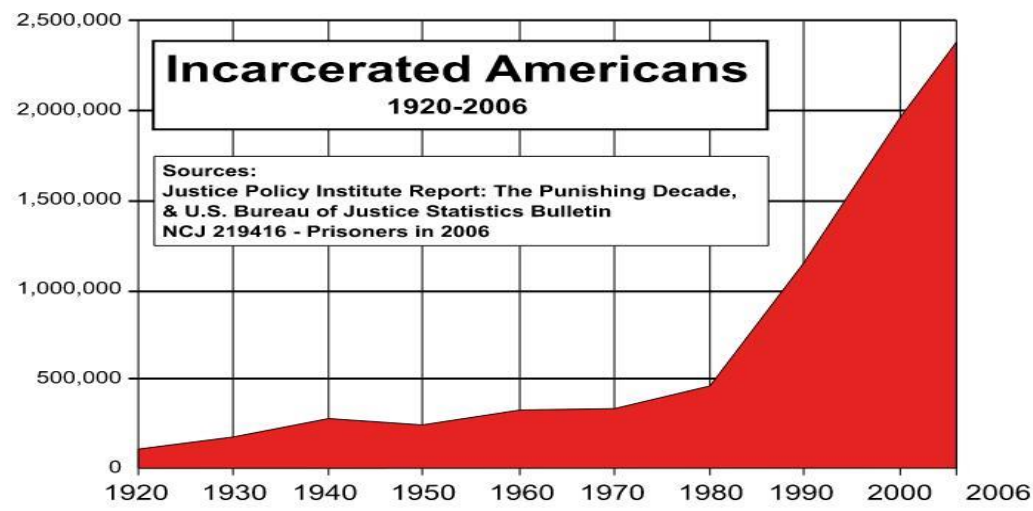

Chart 1 Increase of prisoners in the United States (1920-2006), (Chang, Thompkins, 2002: 51).

Chart 1 shows the increase in number of incarcerated prisoners in the United States since the beginning of the 20th century until 2006. In the period 1920-1940, the number of prisoners reached the figure of 250,000 prisoners and detainees. It had a tendency of a moderate growth until 1980s, when the number steadily increased and reached the figure of 500,000 detainees in the US prisons in early 1980. This is followed by a sharp rise in the prison population, reflected in the massive 1,000,000 prisoners in 1990. This is attributed to a rise in crime in the United States and the inadequate treatment methods applied among prisoners in this period, particularly the work treatment. As illustrated in the graph, the prison population kept rising, the result of which was a figure of 2,500,000 detainees in the US penitentiary institutions in late 2006 (Chang, Thompkins, 2002: 51).

On the other hand, there was considerable criticism on how private prisons and convicts work will be monitored and controlled, particularly in terms of prisoners' successful re- 
socialization and protection of human rights related to working conditions, remunerations, etc. Another objection concerning the the privatization of prisons, which is philosophical rather than legal, is the question whether it is fair and just that the fee for the prisoners' work in private prisons be transferred to private companies.

Also, we touched on the impact of convict labor on trade unions and trade union strategies to combat the spread of corporate power in the penitentiary system. In the end, it seems that economy is a form of slavery. Criminologists have found that the increase in unemployment, poverty, income inequality, racial conflicts, and political conservatism contribute to increasing incarceration rates, regardless of the rate of crime. These findings support the theory that the dominant class (struggling to retain its lead in the class, racial and social hierarchy) uses prisons as a means of political, economic, and social control over the "dangerous classes": the unemployed, the poor, the homeless, the mentally ill, political dissidents, racial, ethnic, social and "other" groups.

In essence, the class struggle is manifested in the form of crime control and imprisonment. When unemployment is low, remuneration for prisoners' work can be equated with salaries in the free market. When unemployment is high, the state is struggling to absorb the growing number of surplus employees and combat social unrest related to economic vulnerability; in such a case, prisoners receive lower wages.

Some research penologists confirmed that when the economy was stagnant, Congress passed several federal laws where many activities were criminalized as offenses involving more severe sanctions and more rigorous law enforcement. The same studies have also documented that the Republican presidents lead the way in enacting legislation in order to attract the working class to vote for them. They also increase the fight against crime at the federal level, expenses and laws against criminals, both of which tend to increase the rate of prison population (Chang, Thompkins, 2002: 46-50).

Taking all this into account, private prisons are characteristic of developed countries and societies with overcrowded prisons and the constant increase in the prison population.

In this regard, the prison industry is directly related to the economic position of the country, where the prisoners' cheap labor is perceived as a chance for a quick profit. Private prisons are a possible option in countries such as Serbia, but it calls for substantial change not only in terms of criminological and penological conceptions but also in terms of changing the mindset of the society as a whole, which should be accompanied by the positive law regulation on private prisons and correctional facilities.

Today, the privatization of prisons implies placing convicts from the existing public and state correctional institutions to work for private organizations, as well as construction and operationalization of new and additional correctional facilities by private (for-profit) prison companies.

Private prisons are one of the biggest controversies in the privatization of public goods. For example, the United States have decided to use the services of private entrepreneurs "who offer better services in this sector", in order to save the state budget. The huge number of prisoners, shown in Chart 1, enables this profitable business to blossom. Private prisons need large numbers of prisoners who enable them to obtain government subsidies, which are further invested in industrial production. The owners of private penal institutions need a smaller number of guards because the prison wards are practically run by the inmates (usually members of certain gangs) so that there are considerable savings on prison staff. Thus, eight prisoners from the Idaho Correctional Center complained: "The company that manages imprisonment saves on staff so that keeping prisoners at the institute ceded most violent gangs whose members are serving their sentences" (Zatz, 2008: 871). 
The savings achieved in this way are not in favor of citizens who as taxpayers fund the prison system; instead, they are more conducive to those whose ultimate aim is to gain profit, either legally or illegally. Notably, no significant fall of the crime rate has been recorded in the states where such institutions have been established (Chang, Thompkins, 2002: 95).

This method of "resocialization" has encouraged even more corruption within the judiciary. In a scandalous affair (known as "Children for Money"), Judge Mark Ciavarella was sentenced to 28 years in prison for accepting a bribe from the owner of a private prison to send an increasing number of juvenile offenders to the juvenile prison, with the aim of employing them in private penitentiary institutions. A court in Pennsylvania said that, sending about 6,000 children to prison, he earned \$ 2.6 million. Out of the total number of detained juvenile offenders, 1,000 to 2,000 juveniles received prison sentences for the crimes they were accused of. The judge was paid to "supply" juvenile prison with young offenders, regardless of whether they were guilty or innocent. Most importantly, these juvenile offenders and their work were intended to bring profit and fill the budgets of private prisons (Gillin, 1929: 234).

In some European countries, politicians came up with the idea to use the American experience. Thus, the parliament agenda included "draft laws on public-private partnership in the prison system, as one of the options for savings in the state budget." In doing so, they disregarded the primary mission of these institutions, which should serve to educate and resocialize the offenders rather than to make profit.

The last in a series of scandalous and discouraging news came from the State of Alabama. A textile factory, which was supposed to produce uniforms for the Ministry of Defense, had to cancel a transaction worth billions of dollars because, according to the law of 1930 (which is still in effect), prison facilities have a favorable position in the procurement procedures organized by state institutions. The textile factory offered the Ministry of Defense the price of \$ 24 per uniform, whereas the penitentiary facility was offered \$ 34 per uniform. Regardless of the huge difference, the penitentiary institution was given this lucrative job. In this case, they are all at a loss: the workers at the plant (who will be fired), the government, taxpayers and prisoners. The only one that gains is the Federal Prison Industries (FPI).

Another striking example is the State of Louisiana. In this state, on every 100,000 inhabitants, 1,000 people are serving a prison sentence. One may think that Louisiana is full of criminals who end up behind bars, or that it is a repressive police state that closes people for the smallest offense. Actually, most prisoners serve their sentences in private prisons; otherwise, the "prison industry" would go bankrupt. According to official data of the Federal Prison Industries (FPI), the "prison industry" generates annual revenue of \$ 182 million (Gillin, 1929: 235).

As a fact of greatest absurdity, local sheriffs are often the "prison entrepreneurs", i.e. the owners of these private institutions. The obvious "conflict of interest" does not bother anyone because, in this way, the local police "pay" the State Prison system, which costs \$ 25 a day per prisoner. Thus, the taxpayers' dollars, which could be used in education or in hospitals, end up in the pockets of private entrepreneurs who have created this system.

In addition to the privatization of the prison system, there is also the system of "disposal" of illegal immigrants. While the governments of countries worldwide are trying to put an end to illegal immigration, civil services (which are to do the task) are deprived of assistance and the job is being outsourced to private prisons. The scandal erupted when information was leaked about the huge salaries in these companies deriving from contracts with the state, while the media reported on grave abuses, neglect and exploitation of prisoners 
in these private institutions. Such practice mainly exists in Australia, the UK and the US. Political leaders are trying to prove to voters that they are strict on the issue of illegal immigration by detaining illegal immigrants.

\section{PRIVATE PRISONS IN THE UNITED KINGDOM}

In modern times, the United Kingdom was the first country in Europe that used prisons managed by the private sector, in order to provide for accommodation and incarceration of its prisoners. Wolds Prison was opened as the first private prison in the UK in 1992. It was one of a number of prisons (originally made by the public sector) which was chartered under a contract to be operated by the private sector for a period of 5 years. Soon, other private prisons were chartered within the Private Financial Initiative (PFI) framework, where contracts were granted to the whole project, construction, operation and financing of the prison, for a contract period of 25 years. Later, the UK government attempted a type of testing in prison under the administration of the public sector, but no public prison is transferred from the public to the private sector. In the procurement procedure, private prisons are required to submit a bid for the institution at the end of each contract period, which has been successfully done in three cases so far.

Private prisons are run by private companies and companies specializing in this kind of work, which have signed agreements with the government. In this regard, certain standards have to be met. Payments can be reduced only if the obligations from the contract are poorly executed. The government authorities constantly monitor and control the work in any private prison, checking the living conditions and treatment of prisoners. Private prisons are also subject to inspection by the Chief Inspector of Prisons, pursuant to the same standards as staterun prisons. In England and Wales, there are now 14 prisons run by private entrepreneurs and private companies (Hedges, 2013: 130).

In Australia and the UK, where this form of privatization has had the fastest progress, companies such as G4S largely benefit from entering new contracts with the government, despite the increasingly frequent scandals over violations of human rights. For example, in a private detention facility in the UK, criminal investigation was conducted last fall over the death of an illegal immigrant. He choked to death while being kept pressed to the floor by three guards. Shortly afterwards, the company lost a contract with the state. However, G4S still has contracts with the British government worth 1.1 billion dollars, of which only 126 million covers the "disposal" of illegal immigrants. While one may think that this is still far away from us, in 2012, Italy adopted a law on private penitentiary institutions, but there were problems with its implementation. Therefore, this extremely inhumane form of profitmaking activities entered Europe through the "back door", via the G4S company in the UK.

\section{CONCLUSION}

The prisoners' labor has been an issue of considerable attention in both national and international penological theory and practice for a long time. During several reformist attempts in the late 19th and early 20th century, penological scientists tried to find an adequate way to influence and promote the application of different forms of prisoner treatment, aimed at successful re-socialization and reintegration. Reluctance and idleness are the issues which are constantly underscored in all the studies as the worst enemy, both 
in the formal system of penitentiary institutions and in private prisons. Prisoners also disapprove of leisure and idleness during the execution of prison sentences.

In developed countries, such as the United States and the United Kingdom, the first modern prisons were established in the late 19th century. However, convicts' work was recognized as a source of funding penitentiary institution and prisoners' needs. The prisoners' labor is primarily important for two reasons. First, it is a source of cheap labor of prisoners who produce goods and provide services that are much cheaper and more accessible than those in the free market. Second, it is beneficial for prisoners themselves because they have a work obligation in the course of serving their prison sentences. Another advantage of convicts' cheap labor is that prisoners can do any kind of work, which is useful for their reintegration into the society.

On the other hand, in addition to being inadequately and disproportionally paid, the downside of cheap convicts' labor is the neglect of convicts' needs, lack of concern about their welfare, and inadequate treatment. The price of convict labor is still below the minimum labor price in the free market, both in our country and in developed countries.

However, developed countries, such as the US, the UK and a few others, extract huge profits from convict labor, often making concessions and adapting the costs of convicts' labor, which creates a specific form of "prison industry". In the US, it has assumed a form of a federal police state, where the US federal government, its laws and regulations of individual states impose an obligation to purchase products of convict labor, even if the price exceeds the price on the free market. This is one aspect to be borne in mind in any future reorganization procedures and consideration of prisoners' work in our penal institutions, which should primarily be aimed at improving the prisoners' living conditions, providing work opportunities for inmates and their financial support, covering the accommodation costs for each convict and, above all, accelerating the prisoners' treatment and re-socialization. Prisoners' labor is the best substitute for retribution and imprisonment, which may reduce if not eliminate the brutality of the prison environment.

In the US, penologists have designed some good working projects, such as field trips and minimum security farming camps, which are largely oriented towards prisoner employment. Another important aspect which the United States have successfully implemented is the legislative impact on this problem, through the adoption of a completely new legislative framework regulating the convict's labor, which is expected to influence and control the crime rate and the prison population rate. In fact, the legislative framework should follow the developments in society, and ensure that the costs of convict labor are equal to the costs of labor in the free market.

In Serbia, in addition to the increase in the crime rate, there is the issue of the increase in the prison population and overcrowding of penitentiary institutions. Roughly speaking, our prisons may accommodate about 8,000 convicts but, at the moment, there are approximately 12,000 prisoners who are currently serving their sentences in different institutions for the execution of criminal sanctions. On the one hand, such a situation may lead to a violation of their fundamental human and prisoner rights. On the other hand, overcrowded prisons are a huge burden for the formal penitentiary system and the state budget. One solution is the establishment of private prisons or, as described in the final part of this paper, entrusting the administration and organization of convicts' work to private companies, which should be constantly monitored and controlled by the public sector and competent authorities of the Ministry of Justice, as it is the case in the UK. 
We know that there is a great discrepancy between developed countries and our country. But, just like the developed countries (such as the US and the UK), our country is faced with similar, if not the same, problems related to punitive approach to the execution of imprisonment of convicted persons, the increasing crime rate and the increasing prison population rate. In the foreseeable future, we need to look at the problems encountered by the developed countries in this segment, consider how they have coped with the emerging issues, make a plan that will suit our current penological situation, and anticipate possible changes in accordance with the political and legal changes that inevitably await the Republic of Serbia in the process of joining the European Union. In this respect, if nothing else, this article may initiate a discussion and give rise to ideas for future theoretical and practical approaches to regulating this burning penal, sociological and economic problem.

\section{REFERENCES}

Busse, M., Brown, S.(2003). "Trade and investment effects of forced labor: An empirical assessment", International Labour Review, Vol. 142, No. 1; ProQuest Education Journals, p. 49-71;

Chang, F., Tracy H., Douglas E. Thompkins.(2002). Corporations Go to Prisons: The Expansion of Corporate Power and the Correctional Industry, Labor Studies Journal, Volume 27, Number 1, pp. 45-69 (Article) Published by West Virginia University Press;

Field, Joseph E.(1987). Making Private Prisons: An Improper Delegation of the Governmental Power, Hofstra Law Review, number 15,3 review, article 8 ;

Gran, Brian; Henry, William. (2008). Holding private prisons accountable: A socio-legal analysis of "contracting out" prisons, social justice, USA, p. 1-9, 21, 54, 93, 180;

Greene, Robert William.(1977) Early Development of the Illinois State Penitentiary System, Illinois, USA, p. 1-9;

Gillin John Lewis.(1929). Criminology and Penology V2: New York, p: 234-236;

Hedges Chris (2013). The Business of Mass Incarceration; Truthdig. pp 130;

McKelvey, Blake. (1934). Prison Labor Problem: 1875-1900, Journal of Criminal Law and Criminology, Volume 25 , p: 267-270;

Reynolds, Morgan O. (1994). Using the private sector to deter crime, National Center for Policy Analysis, DallasTexas, USA, pp. 33-52;

Smith Adam (2005).An inquiry into the nature and causes of the wealth of nations, AN Electronic classics series publication of The Pennsylvania State University, p: 10;

Wade, Lisa (2013). Prison labor and taxpayer dollars, p. 1;

Zatz, Noah (2008). Working at the boundaries of markets: prison labor and the economic dimension of employment relationships, UCLA School of Law, University of California, Los Angeles, p: 868-871.

\section{NOVA FUNKCIJA ZATVORSKE INDUSTRIJE I PRIVATNI ZATVORI U RAZVIJENIM ZEMLJAMA SVETA I MOGUĆNOST IMPLEMENTACIJE ISTIH U REPUBLICI SRBIJI}

Problemi vezani za rad osuđenih lica, devedesetih godina bili su sve više zasebno rešavani u raznim državama sveta. Samo u takvim razvijenim saveznim državama SAD-a kao što su Njujork, Pensilvanija, Masačusets, rad osuđenika je mogao opstati jer su ove države bile u stanju da se nose sa teretom neproduktivnih zatvora. Uređenjem kaznenog zakonodavstva u ovim saveznim državama, zajedno sa uticajem reformatora penološke misli u SAD-u, stara američka tradicija zatvora podržanih radom svojih zatvorenika ustupila je prostor novom standardu rada osuđenika koji će da uče zanate ali će biti isključeni sa javnog tržišta rada na slobodi. Novi industrijski program, koji je nastao iz svega toga, ipak je mnogo doprineo širenju reformatorske funkcije zatvorskog rada. Organizovani zatvorski rad, koji je oduvek bio jak na severu Sjedinjenih Američkih Država, tokom sredine osamdesetih godina, izgubio je mnogo kako na političkom nivou, tako i u zakonodavnom uticaju, nakon što su se penolozi reformatori 
povukli iz toga dela SAD-a. Uticaj reformatora i uopšteno same ideje o radu osuđenika, ali bez konkurisanja na tržištu, proširilo je kroz državne i okružne skupštine snažan uticaj na državne političare. Uzrok borbe reformatora je bio blagostanje zatvorenika i omogućavanje rada svim osuđenim licima, gde bi oni učestvovali kao konkurentna radna snaga na tržištu, kako preko iznajmljivanja radne snage tj. zatvoreničkog rada, tako i preko prodaje konačnih proizvoda na slobodnom tržištu.

Ključne reči: rad osuđenih lica, neproduktivni zatvori, blagostanje zatvorenika, konkurentna radna snaga. 